\title{
Incidence of Energy Poverty in Nigeria: A Critical Assessment
}

\author{
Obafemi, Frances Ngozi \\ Department of Economics,University of Calabar, Calabar Nigeria \\ francesobafemi@yahoo.co.uk \\ Ifere, Eugene Okoi \\ Department of Economics,University of Calabar, Calabar Nigeria \\ eugeoifere@yahoo.com,eugeoifere@gmail.com
}

\begin{abstract}
Despite abundant energy sources in Nigeria, three major strategic challenges militate against its efficiency. The aftermath of this inefficiency is health risk, increasing energy prices, low socioeconomic status of the population, increased National debt burden, and rising inflation and massive unemployment. This study is set out to consider an apt remediation for this state of affairs. Using random sampling, households are surveyed in six states of Nigeria and Abuja Federal Capital Territory across the six geopolitical zones. Electricity tariffs, Energy gaps between the high and low income earners, energy spending needs and incomes against a fixed threshold were investigated. A comparison from the income earned shows that above 10 percent of income earned are spent on energy; that both the high and low income earners are energy poor, but the low are more severely hit. The results show that the energy poverty from high energy cost and inefficiency fuels income inequality.
\end{abstract}

Keywords: Energy Poverty, Energy Efficiency, Energy Security

\section{INTRODUCTION}

Nigeria, a country with vast oil and gas reserve, abundant sunlight and significant hydropower potential is worst hit in the paradox of Energy poverty and incessant energy price hike and energy insecurity. Energy poverty appears to be one of the most striking with per capita electricity consumption falling below 150kwh ,Simire,[15] This situation is causing untold widespread poverty among the about 175 million inhabitants, for decade's hence economic bleakness. In the energy ladder, a great number of Nigerians are climbing down the energy ladder - moving from electricity, gas and kerosene to fuel wood and other traditional biomass energy forms. A sizable number of about 112 million people can be said to depend solely on wood as a source of fuel for cooking thus contributing to the buildup of greenhouse gases (GHGs) that cause climate change.

This paper conceptually defines energy poverty in Nigeria to mean a condition characterised by poor quantity and quality of energy services, in terms of accessibility, affordability, sustainability. It focuses on the amount of personal monthly income committed towards energy consumption. It includes payment for fuels (for driving cars and powering generating sets and other heating regimes) .Under this condition, one is said to be energy poor when more than $10 \%$ of his monthly income is used for satisfying energy regimes and when there is no sustainable, modern, affordable and reliable energy services. It also holds that firewood as a 
source of energy is not only for rural areas, but it is also the energy of choice for the semi urban and urban poor who could not afford modern, clean energy services.

Energy poverty has been a persistent problem for almost every Nigerian with no end to high energy prices in sight. This is because, a household is said to be in fuel poverty if it needs to spend more than $10 \%$ of its income on fuel to maintain a satisfactory heating regimes. Fuel poverty is largely down to three factors- income, energy prices and energy efficiency U.K.parliament ,[13]. Higher fuel prices have led to the doubling of fuel poverty in Nigeria. There are expectations of higher increases, if not cut in the bud. Government actions through energy efficiency policy are the smart way to cut "energy hurricane" in the bud.

Therefore, the only cushion to reduce energy bills and fuel poverty is a policy towards energy efficiency. Prices of fuels, gas and electricity have increased for most of the last decade in Nigeria with little prospects and hope of sustained reversal in these trends. The many reasons for these increases in prices and fuel poverty is the declining output in fuel refining or the death of the Nigeria refineries, sabotage and the system of neo- liberal capitalism that encourages the ruling cabals to import fuel into the country in order to make profits. Since rise in energy price have impacts on the citizens, industry, economic growth and inflation, therefore, it would cause fuel poverty and add to economic uncertainty. The last (2012) subsidy schemes lead producers to sell crude overseas rather than to local refineries and therefore add to increasing volumes of refined products imports. The cost of energy is blamed for the collapse of textiles and auto manufacturing industries in Nigeria (Shaad and Wilson,[14]. The level and cost of fuel utilization and energy price rise in an economy are directly indicative of the level of development of the economy. In order to ensure optimal, adequate and reliable and secure supply of fuel that can bring down energy prices, therefore, it is pertinent to put in place a coordinated, coherent and comprehensive fuel and energy policy for the country.

This paper measures the depth of energy poverty in Nigeria, and proposes way forward to checking the paradox of energy poverty in the midst of abundant energy resources.

\section{THE PROBLEM}

Despite abundant energy sources in Nigeria, three major strategic challenges militate against its efficiency. These comprise the disruptions to its supply, environmental damage during production and usage, and persistent energy poverty. The aftermath of this inefficiency in energy exploitation is health risk, increasing energy prices, low socioeconomic status of the population, increased National debt burden, with attendant rising inflation and massive unemployment. Equally, persistent shutdown in power generation sources, high cost of energy distribution and bad debt loss from ineffectual collection procedures are aftereffects of this ineptitude

It was in the light of the foregoing issues that the present study was designed towards investigating and clarifying the impacts, causes and problems of energy poverty on the economy of Nigeria. It is poised to unravel why Nigeria as a nation with abundant fuel and energy resources is still wallowing in energy poverty, caused by excessive energy price hike which may add to poverty, inflation and economic uncertainty.

The paper is divided into four sections. After the introduction, Part two discuses theoretical underpinnings of Energy price in Nigeria, part three talks about fuel poverty which is caused directly or indirectly as a result of energy price hikes. Method of analysis and discussion of 
results from primary data to ascertain the true position of energy poverty is carried out in section five. Part six houses the policy recommendation and conclusion for the study.

\section{THEORETICAL UNDERPINNINGS OF ENERGY PRICING}

A lot of theories by different schools of thought have been propounded on the different approaches to energy pricing among the few ones are;

\section{The Market Based Approach.}

This approach also known as the world parity, border price or opportunity cost approach is anchored on the traditional economic principles of demand and supply. Odoko etal [10] sees price of petroleum to be determined thus;

Where

$$
P p=f(p w+C R+T c+D c+O c)
$$

$\mathrm{pp}=$ pump price of petroleum product

$\mathrm{Pw}=$ world price of crude oil at international markets

$\mathrm{Cr}=$ Cost of refining fuel

Tc $=$ Transportation cost

Dc $=$ Distribution cost

Oc $=$ other cost in the course of production (taxes etc)

The underlying principle of this approach is synonymous to market demand and supply interplay like any other normal economic commodity in an imperfect condition. According to Odoko et al. [10], in the case of an oil producing country, pricing using this approach is based on the principle of opportunity cost which is the world price already determined by forces of demand and supply. That domestic price will be the border price, less freight and other relative charges. This approach eliminates the arbitrage opportunities engendered by lower domestic prices, vis- a vis international prices ,Odoko et al [10]. Smuggling of fuel due to lower domestic prices as a result of subsidy could also constrain domestic supply in the long run and cause resource misallocation or inefficiency in use.

\section{The Exhaustible Resource Theory}

This school of thought championed by Hotelling (1931) in his works argues the need to price oil and other fossil resources so that the temporariness of this existence will come to bear. This school holds that price becomes a user cost, or depletion charge to show for exhaustion of resources which access is denied of the future generation.

\section{Capital Replacement Approach.}

The capital replacement school of thought advocates the need for petroleum products pricing bearing in mind the cost of production and refining. This approach argues that petroleum products should be priced in such a way that all the costs of production are recovered. This theory is critiqued in that petroleum pricing are not mutually exclusive. According to Odoko et al [10] it is possible for equilibrium price in the market based approach to be consistent with that of capital replacement approach if prices reflect the true market cost and there are no divergences between international and domestic prices.

A blend of all the petroleum pricing approaches will be more acceptable in Nigeria. However, a pricing policy that seeks to equalize domestic and international prices which does not consider the capacity of consumers to pay and does not provide variety of social benefits that can compensate for the effects of high prices is unhealthy to the economy. 
The argument that supports petroleum pricing that considers capacity of consumers to pay interest of future generation, guarantees the highest social revenue, that does not make asset too cheap and avoid wasteful consumption is more acceptable. In this case pricing (based on cost of production) margin accruing to government should be made to decline so that consumers will at least enjoy some leverage given that the resources are tapped from Nigeria and not alien.

\section{ENERGY PRICE RISE IN NIGERIA.}

The pricing of petroleum products and energy has always evolved passion and controversy in the nation's body polity (Odoko et al [10]. The pricing of fuel transcends to energy such as electricity, since electricity are powered through fuels (gas, Petroleum, coal etc). The dragging debate on this issue has been centered on the question of whether the pump price of fuel should reflect the full cost of production. However, other contending arguments are that subsidy on petroleum products are a burden on government as it will impede development. Another argument is that appropriate pricing of petroleum products without subsidy will enhance adequate supply and distribution and this will generate available savings for government for infrastructural development. Most passionate is the argument that given the critical role of oil in the Nigerian economy, pricing domestically -consumed crude at export parity is insensitive to the plight of Nigerians, majority of whom live below the poverty line and the wide wage differentials between industrial and developing countries and differentials in exchange rate. Electricity bills are consistently reviewed upwards even with the incessant power outages. This trend, which would have been revised, is due to unavailability of gas supply to power thermal turbines.

The cost of petroleum products in Nigeria which makes up the actual cost of product is determined by the summation of all relevant cost components which include crude oil exploration, field development, production, refining, distribution and marketing. The current pump price of petroleum in Nigeria (as at 2012) is N97.00/litre. This price which is established by regulation is inclusive of subsidy. With the removal of subsidy by the federal government which according to SUPA (2010) can be determine as actual cost of petrol sales price therefore fuel price has gone very high and this has invariably affected the economy and caused energy poverty.

For imported fuel as in the case of Nigeria (which export crude and import refined petroleum products due to none functioning of refineries) there is usually unnecessary additional cost in the form of cost of transportation from the source country to Nigeria, changes such as port charges, taxes and export duties at source country, cost of insurance and transportation of products, cost associated with international crude oil sales, cost of brokerage for agents.

\section{Energy Poverty in Nigeria}

The trend in prices of fuel be it black market or legal pump prices have led to energy poverty doubling in Nigeria. As seen by the further increases by the removal of fuel subsidy by government in 2011. Massive increase in money from consumers pocket to pay for fuels is sucking the life out of the economy. With this increasing rise in energy prices caused by inefficient fuel supply, it shows why our economy is not doing well of late, even when we have abundant energy resources and oil; we still import fuel to supplement the demand.

Road fuels, cost of powering electricity generators have been more volatile for decades and the long term trend has been consistently upwards. Premium motor spirit (PMS) or petrol is the most widely demanded and utilized petroleum product in Nigeria. 
Wood fuel which is most common fuel in rural areas is getting more expensive as it takes much time to gather and contributes to deforestation. Cooking can be said to be a major energy need in Nigeria, because it involves both the rich in urban cities and the poor in rural villages.

For the middle class of the rural and urban, kerosene used for cooking is in high demand and expensive, most times in short supply as consumers queue in long lines on end without getting any. While cost of gas for cooking and driving of electricity turbines which in ordinary sense would have been considerable as option is made high due to flaring and inadequate supply for domestic consumption. According to Hammond et al, (2007), Nigeria's poorest household earn \$1-2 USD per day, but they spend on average 0.40 USD per day on their energy needs.

In Nigeria, households and businesses spend well over $10 \%$ of their income in just trying to meet up with energy demand; be it cooking, road fuels electricity etc. Energy prices have been proportionately higher for industries and have direct impact on costs and competitiveness, especially for transport companies and energy intensive industries (www.parliement .uk, 2011). Every economy, both developed and emerging depends solely on energy for effectiveness. The tariff by communication companies, cost of transportation, Electricity to light up buildings and almost the cost of all economic activities have gone very high due to direct or indirect impact of cost of fuels to power economic activities.

According to business monitor international[2], to check this ugly trend of fuel poverty, NNPC has signed contracts to swap crude for products under yearly contracts with Trafigura an oil trading company, and Cote d'voire's national refiner SIR.

According to Odoko etal in CBN (2003), some of the causes of fuel poverty as a result of shortages and price hikes are inadequate capacity of ports, pipelines and depots, frequent strikes by tanker drivers at the slightest provocation, corruption and recent militancy and kidnapping in the Niger Delta.

According to United Nations estimates, if nothing is done by 2030, 900 million people will not have access to electricity, 3 billion people will still cook with traditional fuels, and 30 million people will have died due to smoke-related diseases and many hundreds of millions would be confined to poverty due to lack of energy access (Practical Action 2012, Eleri et-al,[4] .

However, some countries have made significant successes in tackling energy poverty some of these countries include; China which connected 500 million people in rural areas since 1990 whilst Vietnam has increased coverage from 5\% to $98 \%$ in 35 years (Energy Poverty guide, October 2011) . Cambodia, Mali and Madagascar have made significant progress by providing support to the private sector from their rural electrification funds. In Bangladesh and Nepal, local operatives owned by consumers are developed to run electricity services.

South Africa which had only one-third of the population at the end of Apartheid in 1994 connected to the electricity grid was doubled ten years late.

Right from 1973, Nigeria has operated a policy of uniform petroleum prices ,Odoko et al [10] where the same price is paid for petroleum products irrespective of location. The Nigerian government over the years has dominated the domestic energy scene by exerting influence in the area of petroleum product pricing. Petroleum prices are fixed by government (either low or high) based on certain prevailing economic situations. 
Table. 1 Comparison of Fuel Price and wage differentials by countries 2011

\begin{tabular}{|l|l|l|l|l|l|}
\hline Country & $\begin{array}{l}\text { Fuel pump } \\
\text { price (Naira) }\end{array}$ & $\begin{array}{l}\text { Country } \\
\text { Minimum wages } \\
\text { Averages (N/ } \\
\text { dollar) }\end{array}$ & $\begin{array}{l}\text { Inflation } \\
(\%)\end{array}$ & $\begin{array}{l}\text { Per Capita GDP } \\
\text { (US \$) }\end{array}$ & Population \\
\hline USA & (N120) & (N277,092) & 3 & 48,100 & $313,232,044$ \\
\hline RUSSIA & & 9.50 & 15,612 & $142,517,670$ \\
\hline NIGERIA & (N65)N95-130 & (N18,000) & 10.8 & 2,600 & $170,123,740$ \\
\hline SAUDI ARABIA & (N25.12 & (N140,694) & 5 & 24,400 & $26,131,703$ \\
\hline UAE & N78.18 & & 2.5 & 49,600 & $5,148,664$ \\
\hline ANGOLA & & & 14.3 & 8,200 & $13,338,541$ \\
\hline LIBYA & $\mathrm{N} 26.69$ & 23,813 & 6.1 & 13,846 & $6,597,960$ \\
\hline EGYPT & & $(\mathrm{N} 78)$ & 13.3 & 6,200 & $83,688,164$ \\
\hline QATAR & $\mathrm{N} 34.54$ & 101,250 & 2.8 & 179,000 & 848,016 \\
\hline ALGERIA & $\mathrm{N} 63.55$ & 55,957 & 4 & 7,300 & $34,994,937$ \\
\hline KUWAITE & $\mathrm{N} 34.54$ & $\mathrm{~N} 161,461$ & 5.6 & 48,900 & $2,595,628$ \\
\hline VENEZUALA & $\mathrm{N} 3.61$ & $\mathrm{~N} 95,639$ & 27.6 & 12,400 & $28,047,938$ \\
\hline IRAN & $\mathrm{N} 102.05$ & 86,585 & 22.5 & 12,200 & $78,868,711$ \\
\hline IRAQ & $\mathrm{N} 59.66$ & $\mathrm{~N} 25,813$ & 6.0 & 3,900 & $31,129,225$ \\
\hline UK & $\mathrm{N} 334.41$ & $\mathrm{~N} 295,644$ & 4.5 & 35,900 & $63,047,162$ \\
\hline & & & & & \\
\hline
\end{tabular}

Source: CIA World Factbook 2012 U.S. Census Bureau, International Database, Wikipedia 2011, IMF 2010, 20002011 Pearson Education, publishing (Note: population is taken mid 2011)

Government fixed prices putting subsidy in during the first era considering the relative influence and stability in exchange rates, which puts Nigeria to compete fairly well with other oil producing countries. But the subsequent prices are fixed with considerations with the prevailing economic realities by opting to remove subsidies in order to check and eliminate Cross-border smuggling of petroleum products and promote efficiency and encourage government saving for infrastructural development.

Table .2 Trend in petroleum (energy) pump price in Nigeria. 1966-2012

\begin{tabular}{|l|l|l|l|}
\hline S/N & Year & Pump Price of Perol/Litre & \% Increase in Price \\
\hline $\mathbf{1}$ & Jan 1966-Sept 1978 & $8(4 / 5)$ Kobo & Nil \\
\hline $\mathbf{2}$ & Oct 1, 1978 & 15(1/2) Kobo & $73.86 \%$ \\
\hline $\mathbf{3}$ & April 20, 1982 & 20 Kobo & $31 \%$ \\
\hline $\mathbf{4}$ & March 31, 1986 & 39(1/2) Kobo & $97.5 \%$ \\
\hline $\mathbf{5}$ & April 10, 1989 & 42 Kobo & $6 \%$ \\
\hline $\mathbf{6}$ & Jan 1, 1989 & 42Kobo (Commercial) \& 60Kobo (Private) & $43 \%$ \\
\hline $\mathbf{7}$ & Dec 19, 1989 & 60 Kobo For all & $43 \%$ \\
\hline $\mathbf{8}$ & March 6, 1991 & 70 Kobo & $16.6 \%$ \\
\hline $\mathbf{9}$ & Nov 8, 1993 & N5 & $614 \%$ \\
\hline $\mathbf{1 0}$ & Nov 22, 1993 & N3.25 & \\
\hline $\mathbf{1 1}$ & Oct 2, 1994 & N15 & $361.5 \%$ \\
\hline $\mathbf{1 2}$ & Oct 4, 1994 & N11 & \\
\hline $\mathbf{1 3}$ & Dec 20, 1998 & N25 & $127 \%$ \\
\hline $\mathbf{1 4}$ & Jan 6, 1999 & N20 & \\
\hline $\mathbf{1 5}$ & June 1, 2000 & N30 & $50 \%$ \\
\hline $\mathbf{1 6}$ & June 8, 2000 & N25 & \\
\hline
\end{tabular}




\begin{tabular}{|l|l|l|l|}
\hline $\mathbf{1 7}$ & June 13,2000 & N22 & \\
\hline $\mathbf{1 8}$ & Jan 1, 2002 & N26 & $18.2 \%$ \\
\hline $\mathbf{1 9}$ & June 1,2003 & N40 & $53.85 \%$ \\
\hline $\mathbf{2 0}$ & June 9,2003 & N34 & $-17.54 \%$ \\
\hline $\mathbf{2 1}$ & Oct 1, 2003 & N39.90 & $17.35 \%$ \\
\hline $\mathbf{2 2}$ & Dec. 2003 & N40.50 & $1.5 \%$ \\
\hline $\mathbf{2 3}$ & May 29, 2004 & N49.00 & $20.98 \%$ \\
\hline $\mathbf{2 4}$ & Jan 1, 2005 & N51.00 & $4.08 \%$ \\
\hline $\mathbf{2 5}$ & Aug 26, 2005 & N65.00 & $27.45 \%$ \\
\hline $\mathbf{2 6}$ & May 29, 2007 & N75.00 & $30.05 \%$ \\
\hline $\mathbf{2 7}$ & 2008 & N65.00 & \\
\hline $\mathbf{2 8}$ & 2011 & N97.00 & \\
\hline
\end{tabular}

Source: Gani Fawehinmi (2003) "Increases in petrol pump price in Nigeria: 1966-2005 as citied by Abifarin (2003:16)

"Merchant of Venom" This Week Magazine. Vol.19, No.3, Akinyele (2011)

\section{Oil Production and Refining in Nigeria}

Nigeria had estimated 37.2billion barrels of proven oil reserves as of January, 2011 0GJ, [11]. While EIA [17] estimates Nigeria's nameplate oil production capacity to have been close to 2.9 million barrels per day (bbl/d)at the end of 2010. In 2010, total oil production in Nigeria was slightly over 2.46 million bbl/d making Nigeria the largest oil producer in Africa. Crude production was boosted to 2.17 million bbl/d for the month of July, 2011 due to offshore and restart of some of some shut in onshore production.

Nigeria total oil export stands at approximately, 2.2 million bbl/d in 2010 and 1.8 million bbl/d of crude oil. Over $980,000 \mathrm{bbl} / \mathrm{d}$ of crude oil and slightly over $1 \mathrm{million} \mathrm{bbl} / \mathrm{d}$ of total oil and products is exported to the United States, making Nigeria the $4^{\text {th }}$ largest foreign oil supplier to US in 2010 EIA,[17]. Even with the large volume of light, sweet quality crude produced in Nigeria, much of its domestic fuel is imported and this can be a factor for fuel poverty and energy price rise. For example, approximately $280,000 \mathrm{bbl} / \mathrm{d}$ of oil was consumed in Nigeria in 2010 and all of this was imported.

In Nigeria, local refineries before now (when functional) receive crude oil produced by companies from their oil mining lease through pipelines from the oil terminals. This crude oil is then refined and sent to retail filling stations through road tankers which get fuel by NNPC or other fuel depots. Due to the non-functioning of Nigerian refineries for some time, imported petroleum products are evacuated from ocean-going tankers. This tankers feed the NNPC and other local depots with petroleum product for onward supply to the fuel stations for consumption. There are four refineries in Nigeria with a total capacity of $500,000 \mathrm{bbl} / \mathrm{d}$. These are;

The Port Harcourt Refinery I; was commissioned in 1965 with an initial installed capacity of $35,000 \mathrm{bbl} / \mathrm{d}$ and further expanded to $60,000 \mathrm{bbl} / \mathrm{d}$. The second refinery is the Warri Refinery commissioned in 1978 with an initial refining capacity of 100,000bbl/d and later upgraded in 1986 to $125,000 \mathrm{bbl} / \mathrm{d}$. the third refinery is Kaduna Refinery, commissioned in 1980 with a refining capacity of $100,000 \mathrm{bbl} / \mathrm{d}$ and later upgraded to $110,000 \mathrm{bbl} / \mathrm{d}$ in 1986 . The most recent was the Port Harcourt II, commissioned in 1989 with 150,000bbl/d installed capacity.

There has been a declining trend in production of petroleum products from the local refineries for as low as 0 and 30 percent capacity. This trend had led to the importing 85 percent of its fuel need, EIA, [17]. Some of the attributed constraints on this refineries are plant equipment failures, management problems etc. 


\section{Impact on the Nigeria Economy}

In the international scene, according to International Energy Outlook IEA [17], oil prices rose in 2011 as a result of growing demand associated with signs of economic recovery and a lack of sufficient supply response. The hike in oil prices at the end of 2010 - 2011 was mainly due to social and political unrest in several Middle Eastern and African economies. That oil prices increased from $\$ 82$ per barrel at the end of November 2010 to more than $\$ 112$ per barrel in day trading on April, 2011. IEO 2011 reference case also predicts that price of light sweet crude oil in the United States to continue increasing in the long term reaching $\$ 108$ per barrel in 2020 and $\$ 125$ per barrel in 3035. All these are cases of substantial uncertainty.

\section{METHODOLOGY}

The study was based on three hundred respondents drawn from the different income strata within six States and Abuja Federal Capital Territory (the states include Cross River-South South;, Enugu-South Eastern; Lagos- South-western; Benue and Abuja FCT -North Central; Kaduna- North Western; Borno-North Eastern) across the six geopolitical zones. Initially Four hundred and Fifty five copies of the questionnaire were sent out. Sixty five (65 per state and FCT) copies of questionnaires were administered randomly on various respondents both selfemployed and salary earners such as, Politicians, Business men and women and the Local villagers of low income in each state. Out of the four hundred and fifty five (455) copies of questionnaires mailed out to the states only three hundred (300copies) were properly completed and returned from the whole respondents. The study was eventually based on three hundred respondents. This number represents the sample size in this study.

The questionnaire was designed in such a manner as to solicit responses in the following areas.

○ Causes (or reasons) for fuel poverty.

- Identification of the problems (or Impact) of fuel poverty on the citizens;

- The various ways through which fuel poverty is perpetrated;

- Evaluation of the possible consequences of fuel poverty on the citizenry and economy in general.

\section{ANALYSIS, FINDINGS AND DISCUSSIONS}

Data collected were analysed using percentages, the arithmetic mean and standard deviation. TheStandard deviation enables us to determine with a great deal of accuracy where the values of a frequency distributions are located in relation to the mean. The standard deviation and the mean of normal population density function help us to determine probabilities of events. As the sample size is sufficiently large (greater than 30) the central limit theorem was applied. According to the Central Limit theorem, even if the population is not normally distributed as the sample size increases, distribution of sample means approaches normality. Thus the application of this theorem enabled us to use the sample size in this study to draw inferences about the population of study without knowing much of the population other than what we got from the sample.

Table 3. Analysis of (monthly) Income level and employment Strata

\begin{tabular}{|l|l|l|l|l|l|l|}
\hline S/No. & Particulars & $\begin{array}{l}\text { No. of Samples that } \\
\text { identified it (X) }\end{array}$ & $\begin{array}{l}\text { Mean } \\
\text { (M) }\end{array}$ & X-M & (X-M) & Percentage(\%) \\
\hline & Employment levels & & & & & \\
1. & Grade level 1-6 & 64 & 66.67 & -2.67 & 7.13 & 21.33 \\
2. & Grade level 7-12 & 60 & 66.67 & -6.67 & 44.49 & 20 \\
3. & $\begin{array}{l}\text { Grade level 12- } \\
\text { above }\end{array}$ & 76 & 66.67 & 9.33 & 87.05 & 25.33 \\
4. & Employment type & 200 & 66.67 & 133.33 & 17776.89 & 66.66 \\
\hline
\end{tabular}




\begin{tabular}{|l|l|l|l|l|l|l|}
\hline 5. & Paid employment & 36 & 66.67 & -30.67 & 940.65 & 12 \\
6. & Self employed & 30 & 66.67 & -36.67 & 1344.69 & 10 \\
7. & Politician & 34 & 66.67 & -32.67 & 1067.33 & 11.33 \\
& Farmer & & & & & \\
8. & Monthly Income & 52 & 66.67 & 14.67 & 215.21 & 11.33 \\
9. & Level & 71 & 66.67 & 4.33 & 18.75 & 23.66 \\
10. & N18,000-N30,000 & 65 & 66.67 & -1.67 & 2.79 & 21.66 \\
11. & N31,000- N75,000 & 82 & 66.67 & 15.55 & 241.80 & 27.33 \\
12 & N76,00-N120,000 & 30 & 66.67 & -36.67 & 940.65 & 10 \\
& N121,000-N200,00 & & & & & \\
\hline & N201,000-Above & & & & & \\
\hline
\end{tabular}

Source : Field Survey November 2012

$$
\begin{aligned}
& \begin{array}{l}
\text { Variance }\left(s^{2}\right)=\sum(\mathrm{X}-\mathrm{M})^{2} \\
\mathrm{n}-1
\end{array} \\
& =\frac{22687.42}{11}=2062.49 \\
& \text { Standard deviation }(\mathrm{s})=\sqrt{2} 2062.49=45.41
\end{aligned}
$$

From the Central Limit Theorem: $\mathrm{Z}=\underline{\mathrm{X}-\mathrm{M}} \quad$ this is exactly standardized when $\mathrm{n} \geq 30$ $\mathrm{S}$

when

$$
\mathrm{X}=300 \mathrm{~s}=45.41 \text { and } \operatorname{mean}(\mathrm{m})=66.67
$$

then

$$
\begin{aligned}
& \mathrm{Z}=\frac{300-66.67}{45.41}=5.14 \\
& \operatorname{Pr}(\mathrm{X} \geq 5.14)=1-\operatorname{Pr}(\mathrm{Z} \leq 5.14) \\
&=1-(0.5000+0.4207) \\
&=0.5000- \\
&=0.0793
\end{aligned}
$$

Based on the above computations the mean $(\mathrm{M})=66.67$ the standard deviation $(\mathrm{s})=45.41$ and the distribution $=0.0793$. These data show that there is 0.0793 probability that the mean will lie outside the standard deviation. This implies that there is about $92 \%$ probability that all the variables mentioned as ways through which income is generated are correct. Since the probability of its correctness is by far greater than its non-acceptance, it is concluded that these are the various ways through which citizens make their income for a living. Also as shown in table 3 income is earned through four major means. These are paid employment, Self employment, Politics and Farming.

Table 4. Analysis of Energy Prices and monthly fuel Expenditure by households.

\begin{tabular}{|l|l|l|l|l|l|l|}
\hline Sr. & Particulars & $\begin{array}{l}\text { No. of Samples that } \\
\text { identified it (X) }\end{array}$ & $\begin{array}{l}\text { Mean } \\
(\mathrm{M})\end{array}$ & X-M & $(\mathrm{X}-\mathrm{M})^{2}$ & $\begin{array}{l}\text { Percent } \\
(\%)\end{array}$ \\
\hline & Car ownership and maintenance & 42 & 83.33 & -41.33 & 1708.17 & 14 \\
1. & one motor bike & 198 & 83.33 & 114.67 & 13149.21 & 66 \\
2. & one car & 40 & 83.33 & -43.33 & 1873.49 & 13 \\
3. & Two cars & 20 & 83.33 & -63.33 & 4010.69 & 6 \\
4. & Above Two cars & & & & \\
\hline
\end{tabular}




\begin{tabular}{|c|c|c|c|c|c|c|}
\hline & fuel Expenditure on Cars/month & 19 & & 64.33 & 4138.35 & 6 \\
\hline 5. & $<\mathrm{N} 5,000$ & 201 & 83.33 & 117.67 & 13846.23 & 67 \\
\hline 6. & $N 10,000-N 20,000$ & 52 & 83.33 & -31.33 & 981.57 & 17 \\
\hline 7. & N30,000-N40,000 & 28 & 83.33 & -55.33 & 3061.41 & 9 \\
\hline \multirow[t]{2}{*}{8.} & N50,000-N70,000 & & 83.33 & & & \\
\hline & fuel Expenditure on Gen./month & 30 & & 53.33 & 2844.09 & 10 \\
\hline 9. & $<\mathrm{N} 5,000$ & 212 & 83.33 & 128.33 & 16468.59 & 70 \\
\hline 10 & N5,000-N15,000 & 38 & 83.33 & 45.33 & 2054.81 & 13 \\
\hline 11 & N16,000- N30,000 & 20 & 83.33 & 63.33 & 4010.69 & 6 \\
\hline \multirow[t]{2}{*}{12} & N31,000 and Above & & 83.33 & & & \\
\hline & Expenditure on cooking fuel /month & 83 & & -0.33 & 0.109 & 28 \\
\hline 13 & $<\mathrm{N} 3,000$ & 207 & 83.33 & 123.67 & 15294.27 & 69 \\
\hline 14 & $\mathrm{~N} 5,000-\mathrm{N} 10,000$ & 10 & 83.33 & 73.33 & 5377.29 & 3 \\
\hline \multirow[t]{2}{*}{15} & N11- N25,000 & & 83.33 & & & \\
\hline & Electricity bills/ Month & 56 & & -27.33 & 746.93 & 18 \\
\hline 16 & $<\mathrm{N} 2,000$ & 232 & 83.33 & 148.67 & 22102.77 & 77 \\
\hline 17 & N3,000-N10,000 & 12 & 83.33 & 71.33 & 5087.97 & 4 \\
\hline \multirow[t]{2}{*}{18} & N10,00 0 above & & 83.33 & & & \\
\hline & & 1500 & & & 116756.63 & \\
\hline
\end{tabular}

Source : Field Survey November 2012

Variance $\left(\mathrm{s}^{2}\right)=\sum(\mathrm{X}-\mathrm{M})^{2}$

n-1

$$
=\frac{116756.63}{17}=6868.04
$$

$$
\text { Standard deviation }(\mathrm{s})=\sqrt{6868.04}=82.87
$$

From the Central Limit Theorem: $\mathrm{Z}=\underline{\mathrm{X}-\mathrm{M}}$ this is exactly standardized when $\mathrm{n} \geq 30$ $\mathrm{S}$

$$
\begin{aligned}
& \text { when } X=300 \quad s=82.87 \text { and mean }(\mathrm{m})=83.33 \\
& \text { then } \mathrm{Z}=\frac{300-83.33}{82.8}=2.61 \\
& \begin{aligned}
\operatorname{Pr}(\mathrm{X} \geq 2.61) & =1-\operatorname{Pr}(\mathrm{Z} \leq 2.61) \\
& =1-(0.5000+0.4955) \\
& =0.5000-0.4955 \\
& =0.0045
\end{aligned}
\end{aligned}
$$

Based on the above computation, the result shows that there is 0.0582 probability that the mean will lie outside the standard deviation. In other words, it means that there is about 99\% probability that all the variables listed such as the number of car ownership, amount of fuel expenditures made on cars, powering electric generators and payment of electricity bills are correct. For the fact that the probability of its correctness is by far greater than its nonacceptance; it is concluded that these are ways by which energy is used and the expenditure trend by households. The Table also reveals that the numbers of people who own and maintain 
at least one car are higher and that expenditure on fuel to drive cars and power generator sets as well as payment for electricity bills per month is above N10, 000 per individual. These can be deduced from the variables identified by over $65 \%$ responses in the study.

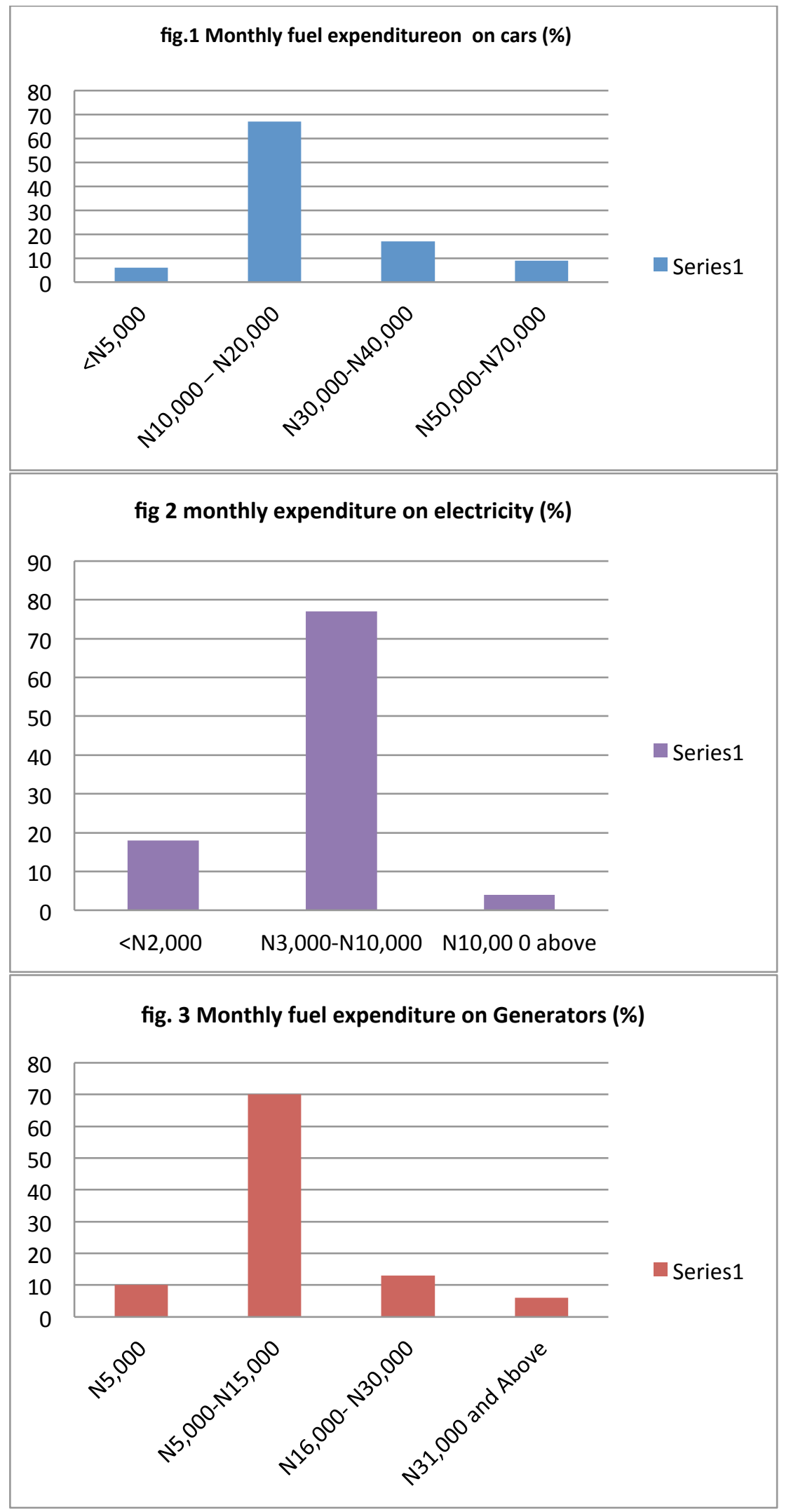


Table 5. Analysis of the extent of comfortability and acceptance of energy poverty in Nigeria

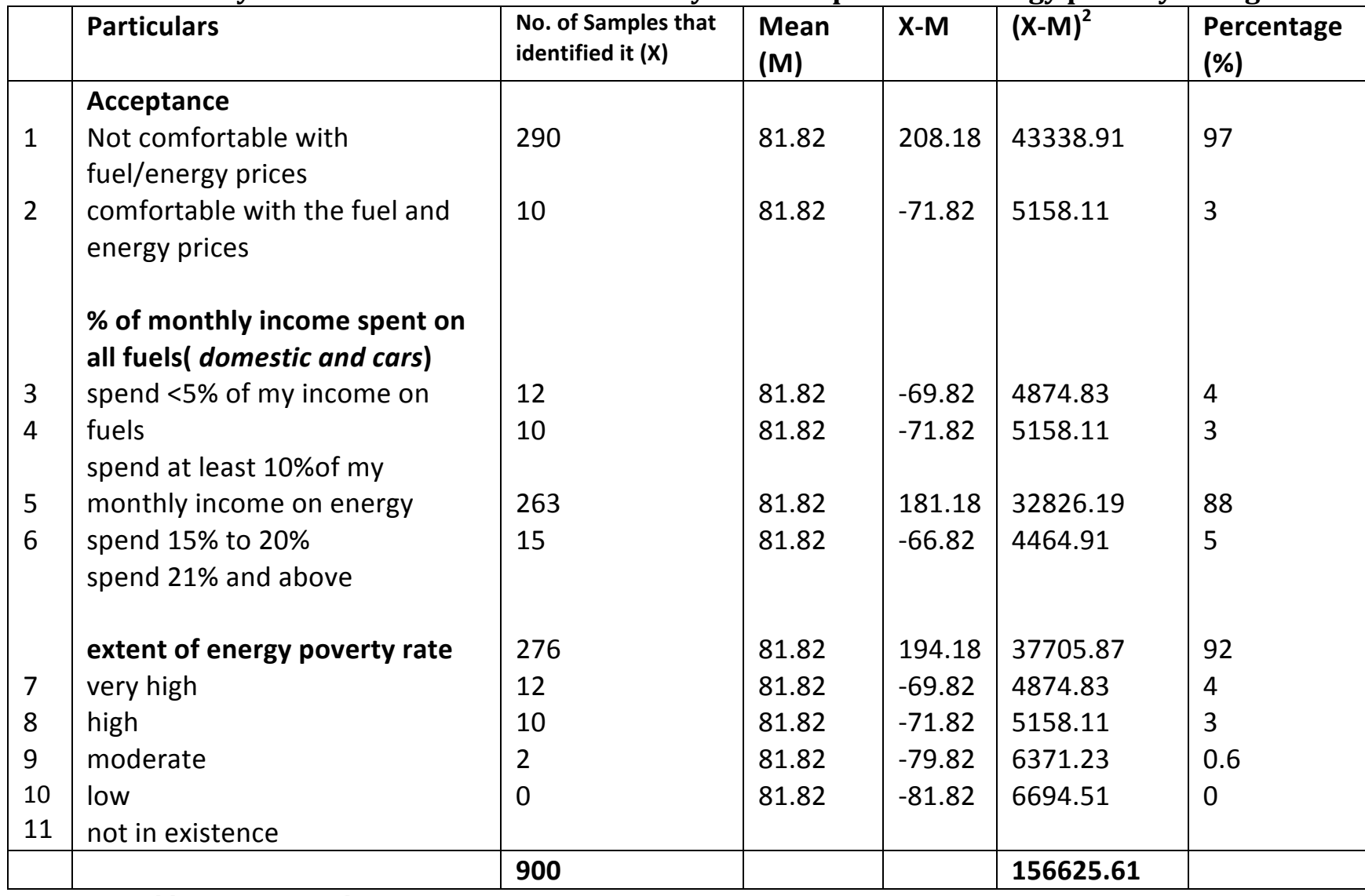

Source : Field Survey November 2012

$$
\begin{aligned}
& \text { Variance }\left(s^{2}\right)=\sum(X-M)^{2} \\
& n-1 \\
& =\frac{156625.61}{10}=15662.56
\end{aligned}
$$

Standard deviation $(\mathrm{s})=\sqrt{ } 15662.56=125.15$

From the Central Limit Theorem: $\mathrm{Z}=\underline{\mathrm{X}-\mathrm{M}}$ this is exactly standardized when $\mathrm{n} \geq 30$ $\mathrm{S}$

$$
\text { when } \mathrm{X}=300 \mathrm{~s}=125.15 \text { and mean }(\mathrm{m})=81.82
$$

$$
\text { then } \mathrm{Z}=\underline{300-81.82}=1.74
$$

$$
125.15
$$

$$
\begin{aligned}
\operatorname{Pr}(X \geq 1.74) & =1-\operatorname{Pr}(Z \leq 1.74) \\
& =1-(0.5000+0.4591) \\
& =0.5000-0.4591 \\
& =0.0409
\end{aligned}
$$

This result shows that there is 0.0409 probability that the mean will lie outside the standard deviation. In other words, it means that there is about $95 \%$ probability that all the variables listed to show the degree of fuel poverty are correct. For the fact that the probability of its correctness is by far greater than its non-acceptance; it is concluded that these are the extent 
or degree of acceptance and percentage of monthly income spent on energy. The table also reveals that citizens are not comfortable with the amount of expenditure on energy per month as it is taking a large chunk of their income leaving them poor. Responses from the study show that as high as above $15 \%$ to $30 \%$ of monthly income is spent on energy and this keeps the citizens uncomfortable. The variables to affirm these facts were identified by over $90 \%$ responses in the study.
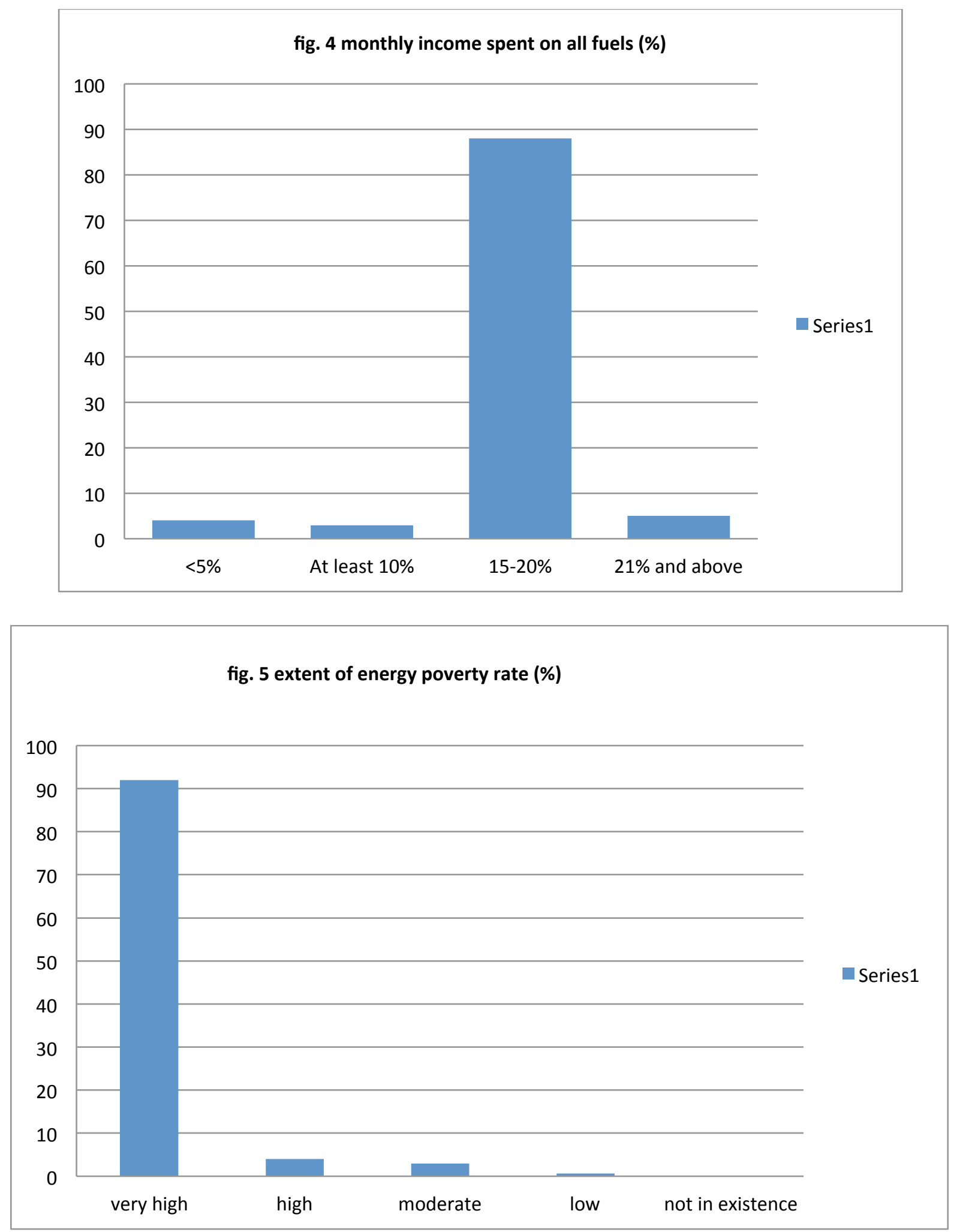
Table 6. Analysis of the causes of energy poverty in Nigeria

\begin{tabular}{|l|l|c|c|c|l|c|}
\hline S/No. & Particulars & $\begin{array}{c}\text { No. of Samples that } \\
\text { identified it (X) }\end{array}$ & $\begin{array}{c}\text { Mean } \\
(\mathrm{M})\end{array}$ & X-M & $(\mathrm{X}-\mathrm{M})^{2}$ & $\begin{array}{c}\text { Percentage } \\
(\%)\end{array}$ \\
\hline 1. & Corruption & 230 & 148.05 & 81.95 & 6715.80 & 77 \\
2. & Military rule & 100 & 148.05 & -48.05 & 2308.80 & 33 \\
3. & Frequent tanker drivers strike & 163 & 148.05 & 14.95 & 223.50 & 54 \\
4. & Distribution bottlenecks & 104 & 148.05 & -44.05 & 1940.40 & 35 \\
5. & Vandalisation of pipelines & 129 & 148.05 & -19.05 & 362.90 & 45 \\
6. & Multinationals & 60 & 148.05 & -88.05 & 7752.80 & 20 \\
7. & Insecurity & 30 & 148.05 & -118.05 & 13935.80 & 10 \\
8. & Short supply of product & 280 & 148.05 & 131.95 & 17410.80 & 93 \\
9. & Non- functional refineries & 276 & 148.05 & 127.95 & 16371.20 & 92 \\
10. & Gas flaring & 231 & 148.05 & 82.95 & 6880.70 & 77 \\
11. & Poor infrastructure & 279 & 148.05 & 130.95 & 17147.90 & 93 \\
12 & Bad road net work & 112 & 148.05 & -36.05 & 1299.60 & 37 \\
13 & Non passage of PIB bill & 109 & 148.05 & -39.05 & 8658.30 & 36 \\
14 & International conspiracy & 60 & 148.05 & -88.05 & 7752.80 & 20 \\
15 & Bunkery & 68 & 148.05 & -80.05 & 6408.00 & 23 \\
16 & Cross boarder Smuggling of & 169 & 148.05 & 20.95 & 438.90 & 56 \\
& petroleum products & & & & & \\
17 & Declining trend in production & 100 & 148.05 & -48.05 & 2308.80 & 33 \\
& of fuel & & & & \\
18 & High cost of production & 165 & 148.05 & 16.95 & 287.30 & 55 \\
\hline & $\quad$ & & 118204.3 & \\
\hline
\end{tabular}

Source : Field Survey November 2012

$$
\begin{gathered}
\begin{array}{c}
\text { Variance }\left(\mathrm{s}^{2}\right)=\sum(\mathrm{X}-\mathrm{M})^{2} \\
\mathrm{n}-1
\end{array} \\
=\frac{118204.3}{17}=6953.19 \\
\text { Standard deviation }(\mathrm{s})=\sqrt{6953.19}=83.39
\end{gathered}
$$

From the Central Limit Theorem: $\mathrm{Z}=\underline{\mathrm{X}-\mathrm{M}}$ this is exactly standardized when $\mathrm{n} \geq 30$ $\mathrm{S}$

$$
\begin{aligned}
& \text { when } X=300 \quad s=83.39 \text { and mean }(m)=148.05 \\
& \text { then } Z=\frac{300-148.05}{83.39}=1.82 \\
& \begin{aligned}
\operatorname{Pr}(X \geq 1.82) & =1-\operatorname{Pr}(Z \leq 1.82) \\
& =1-(0.5000+0.4656) \\
& =0.5000-0.4656 \\
& =0.0344
\end{aligned}
\end{aligned}
$$

From the above computations the mean $(\mathrm{M})=148.05$ the standard deviation $(\mathrm{s})$ is 83.38 and the distribution $=0.0344$ This shows that there is 0.0344 probability that the mean will lie outside the standard deviation. In other words, it means that there is about $96 \%$ probability that all the variables listed as causes of energy poverty in Nigeria are correct. Since the probability of its correctness is by far greater than its non-acceptance we can conclude that these reasons are actually the causes of energy poverty. As could also be observed in the table, 
there are five major causes of energy poverty in Nigeria. These are corruption $77 \%$, short supply of products 93\%, non functional refineries 92\%, and gas flaring 77\%, poor infrastructure $93 \%$. All of these causes have a percentage of $75 \%$ and above.

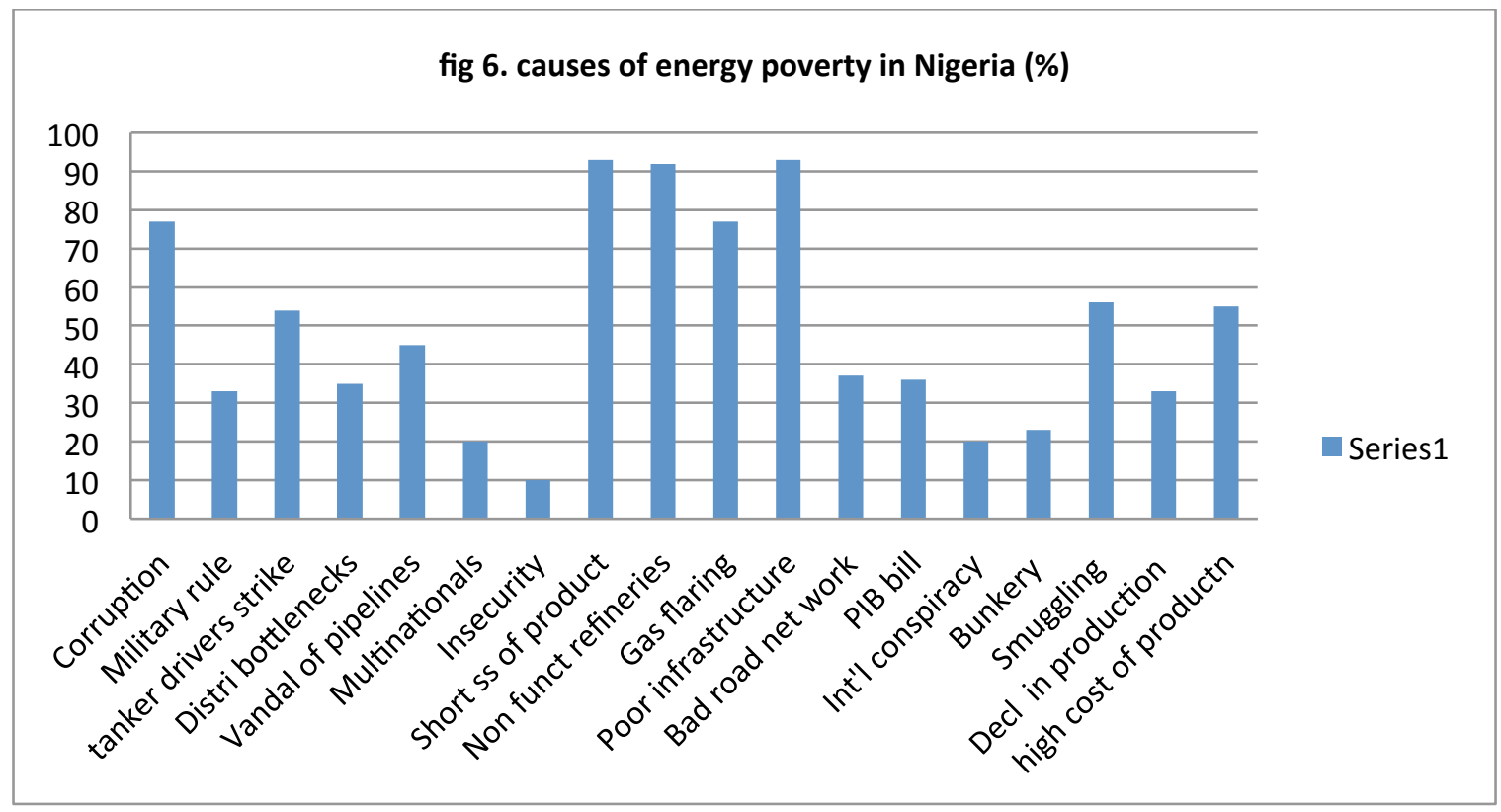

Table 7. Analysis of economic and social Consequencies of high energy cost on Nigerians

\begin{tabular}{|l|l|l|l|l|l|l|}
\hline S/No. & Particulars & $\begin{array}{l}\text { No. of Samples } \\
\text { that identified } \\
\text { it (X) }\end{array}$ & $\begin{array}{l}\text { Mean } \\
\text { (M) }\end{array}$ & X-M & $(\mathrm{X}-\mathrm{M})^{2}$ & $\begin{array}{l}\text { Percen } \\
\text { tage(\% } \\
\text { ) }\end{array}$ \\
\hline & & 284 & 235.89 & 48.11 & 2314.57 & 95 \\
1. & Low real income & 200 & 235.89 & -35.89 & 1288.09 & 67 \\
2. & High poverty level & 235.89 & 9.14 & 83.54 & 82 \\
3. & $\begin{array}{l}\text { High cost of economic } \\
\text { activities }\end{array}$ & 245 & 235.89 & 54.11 & 2927.89 & 97 \\
4. & Economic uncertainty & 290 & 235.89 & 40.11 & 1608.81 & 92 \\
5. & incessant power outages & 276 & 235.89 & -1.89 & 3.57 & 78 \\
6. & energy inefficiency & 234 & 235.89 & 55.11 & 3037.11 & 97 \\
7. & collapse of industries & 291 & 235.89 & -133.89 & 17926.53 & 34 \\
8. & inflationary pressure & 102 & 235.89 & -34.89 & 1217.31 & 67 \\
9. & high cost of electricity bills & 201 & & & & \\
& & & & & 30407.42 & \\
\hline
\end{tabular}

Source : Field Survey November 2012

$$
\begin{gathered}
\begin{array}{c}
\text { Variance }\left(\mathrm{s}^{2}\right)=\sum(\mathrm{X}-\mathrm{M})^{2} \\
\mathrm{n}-1
\end{array} \\
=\underline{30407.42}=\begin{array}{c}
3800.93 \\
8
\end{array} \\
\text { Standard deviation }(\mathrm{s})=\sqrt{3800.93}=61.65
\end{gathered}
$$

From the Central Limit Theorem: $\mathrm{Z}=\underline{\mathrm{X}-\mathrm{M}}$ this is exactly standardized when $\mathrm{n} \geq 30$ 


$$
\begin{aligned}
& \text { when } X=300 \quad s=61.65 \text { and mean }(m)=235.89 \\
& \text { then } Z=\frac{300-235.89}{61.65}=1.04 \\
& \begin{aligned}
\operatorname{Pr}(X \geq 1.04) & =1-\operatorname{Pr}(Z \leq 1.04) \\
& =1-(0.5000+0.3508) \\
& =0.5000-0.3508 \\
& =0.1492
\end{aligned}
\end{aligned}
$$

In analyzing the economic and social consequences of high energy cost on the Nigerian citizens, the results shows that; the mean $(M)=235.89$ the standard deviation $(s)$ is 61.65 and the distribution $=0.1492$. This shows that there is 0.1492 probability that the mean will lie outside the standard deviation. In other words, it means that there is about $85 \%$ probability that all the variables listed as economic and social consequences of high cost of energy in Nigeria are correct. Since the probability of its correctness is by far greater than its non-acceptance we can conclude that these are actually the consequences of high energy cost. As could also be observed in the table, there are very many consequences of high energy cost which transcend to fuel poverty in Nigeria. These low real income, high poverty rate, high cost of doing business, economic uncertainty, incessant power outages and collapse of industries. All of these consequences have a percentage of $82 \%$ and as high as $97 \%$.

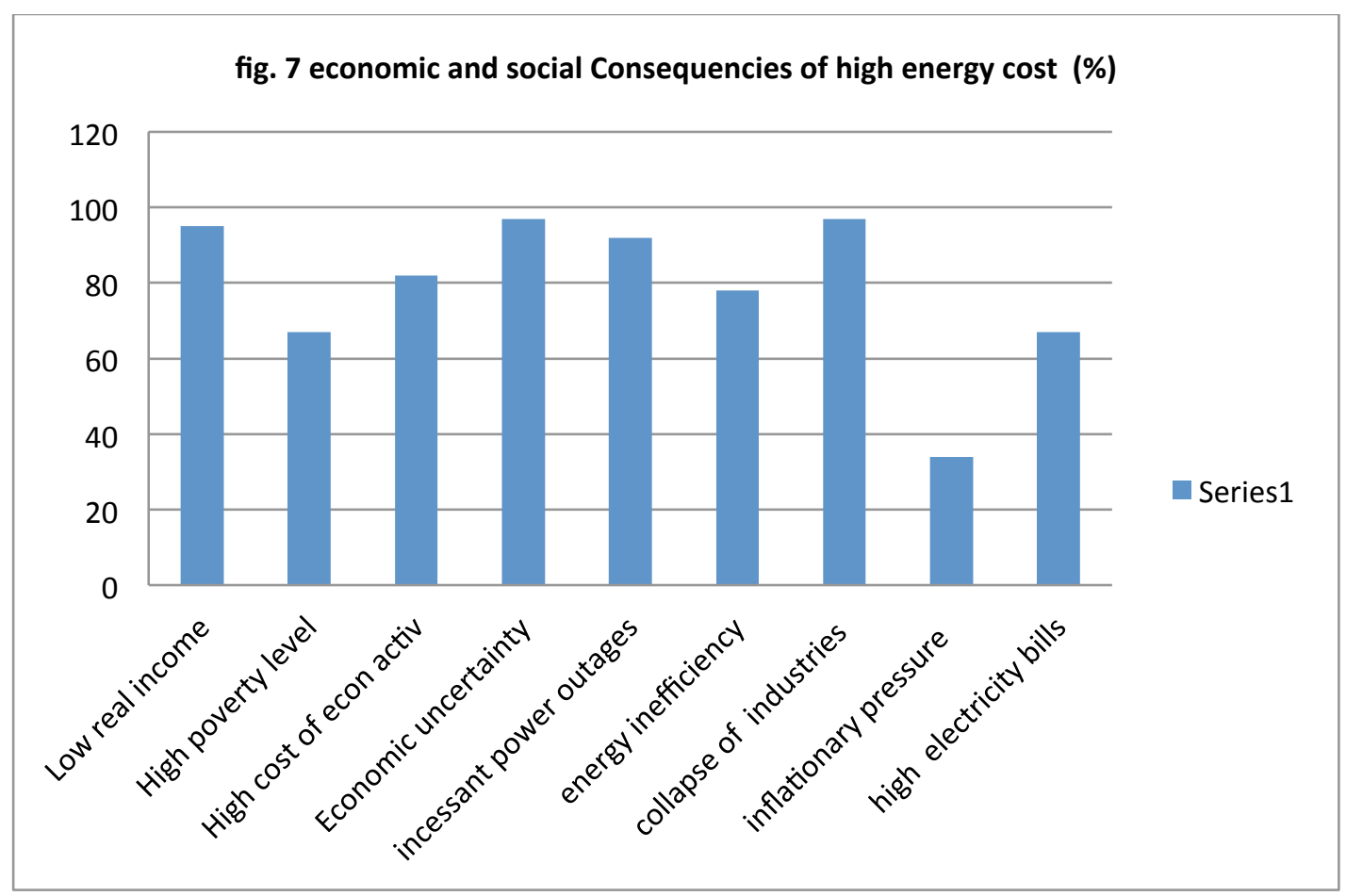

\section{CONCLUSION}

Despite abundant energy sources, Nigeria is worst hit in terms of Energy poverty and incessant energy price hike and energy insecurity. This situation is causing untold widespread poverty among the teeming population, for decade's hence causing economic bleakness. This is because energy is a key to economic development and political stability. Energy poverty has been a persistent problem for almost every Nigerian with no end in sight

From all indications it is now clear that the only cushion to reduce energy bills and energy poverty to a tolerable level is a policy towards energy efficiency which entails reaching an 
informed judgment on the pricing, availability and sustainability of energy in Nigeria to avoid the untold energy poverty that has been lingering on for decades.

\section{RECOMMENDATIONS}

For Nigeria Governments to solve the teething problem of energy poverty it would be appropriate to take a look at the factors responsible for the incidence of energy poverty since a check on these factors will go a long way in reducing if not eradicating the problem. In the light of this, the following recommendations are made:

○ All refineries must be put on stream by proper overhaul to maximize local refining capacity utilization.

- Customers must be provided with transparent and comparable information on energy use and prices in order to enable them to reduce their energy spending

- Improve oil and gas development and production efficiency to reduce cost.

- Improve distribution network by setting tank farms in all the geopolitical zones to ease free flow and supply of products to control scarcity.

- Using railways as an alternative means of transporting petroleum products

- Adopting a physical policy of direct involvement in distribution by NNPC to check the excesses of independent tanker drivers.

- Stop importation of fuel of any sort

Increase storage region in times of unforeseen circumstances.

- Government should construct new transmission lines to improve power supply.

- Fast tracking and passage of the Petroleum industry Bill (PIB) to reform the entire energy sector. This Bill would bring in three measures: an energy efficiency programme to bring existing homes up to current energy efficiency levels; social tariffs to limit vulnerable households' exposure to high energy bills; and reinforcement of the legal duty on the Government to act to end fuel poverty.

- Alternative energy sources such as solar energy, biomass and wind energy should be annexed to provide the necessary power generation levels

\section{References}

[1] Akinyele, S.T. Strategic marketing management in the Nigerian oil and gas industry: A theoretical framework. APJRBM, 2011 (2) 1.

[2] Business monitor international, 2011 Retrieved November, 2012 from

http://www.marketresearch.com/Business-Monitor-International

[3]Clinton, H. R.,Energy diplomacy in the $21^{\text {st }}$ century,2012 paper presented at Georgetown University, Washington DC.

[4] Eleri, E O. et al., Expanding access to pro-poor energy services in Nigeria; 2012, International centre for energy, environment \& development. Retrieved October 2013 from http://www.iceednigeria.org

[5] Energy Poverty guide, October 2011

http://uk.oneworld.net/guides/energy_poverty?gclid=CNKh6bvp1K4CFYMRNAodUFH1aw

[6] Friedman, T. L., Hot, flat, and crowded, 2008 . Farrar, Straus, and Giroux, New York, NYhttp://www.decc.gov.uk/en/content/cms/funding/fuel_poverty/hills_review/hills_re view.a spx pg. 154-158

[7] Hotelling, H. (1931) The Economies of exhaustible resources as in Samii, M.V."Oil Revenues and absorptive capacity of an exporting country: A case of Iran. ,1980 OPEC Review (4)2

[8] IAEE Energy Economics: A place for energy poverty in the agenda? 2006, the energy journal, (28) 3. 
Obafemi, F. N. \& Ifere, E. O. (2014). Incidence of Energy Poverty in Nigeria: A critical assessment. Advances in Social Sciences Research Journal, 1(4), 1-18.

[9] Mordi,M. C. Combating energy poverty in Sub-Saharan Africa diplomatic curier.,2012

[10] Odoko, F. O, et al.,The pricing of crude oil and refined products in the Nigerian economy'as in CBN.,2003 contemporay economic policy issues in Nigeria. Ed Nnana, Alade and Odoko

[11] Oil and Gas Journal (2011)

[12] Oil Price.com Why high gasoline prices are causing the drop in GDP Growth.,2012

[13] www.parliament. Uk, (2011) fuel poverty

[14] Shaad , B. and E. Wilson, Access to sustainable energy: what role for international oil and gas companies?2009 focus on Nigeria' IIED, London.

[15] Simire, M., Why more Nigerians are climbing down the energy ladder.2012 retrieved from http://www.environewsnigeria.com/2012/08/06

[16] The World Factbook, 2010

[17] US Energy Information and administration EIA, Nigeria analysis Brief.2011, www.Eia.gov/steo/pub/content.html

[18] This Week Magazine. Vol.19, No.3 2012 